\title{
The Effect of Using Guessing Game Media Themed Local Tourism on Students' Achievement in Writing Narrative Text
}

\author{
Irma Khoirot Daulay ${ }^{1}$, Kristina Br. Hasugian ${ }^{2}$ \\ ${ }^{1,2}$ Universitas Prima Indonesia \\ Kristinahasugian72@gmail.com,irmakhoirotdaulay@unprimdn.ac.id
}

\begin{abstract}
The research was conducted to discover the effect of using guessing game media themed local tourism on students' achievement in writing narrative text. The research was conducted to the grade tenth students of SMA GKPI PAMEN. This research used experimental design. To collect the data 2 classes get involved. There are X-1 as the experimental class that taught by using the guessing game media and X-2 as the control class that taught using the conventional method. The students consist of 30 students. In experimental class, the mean score for the pre-test was 45,46 and the score of post-test was 81,4. In control class, the mean of pre-test score was 46,5 and the post-test was 73,06. The analysis of the t-test showed that tscore > ttable or 3,53>1,672 at the level of significance 0,05 with the degree of freedom (df) 58. The alternative hypothesisi $(\mathrm{Ha})$ is accepted. It point out that using guessing media themed local tourism is effective in teaching writing narrative text for the tenth grade students of SMA GKPI PAMEN.
\end{abstract}

Keywords

guessing game media; narrative text; writing

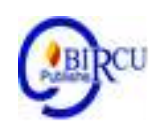

\section{Introduction}

Writing becomes one of the important skills in learning English. Writing is a productive skill need to use appropriate words that make the reader understand and feel interest with every sentences has written. Writing also a process for people in producing language which required time for more to think even in choosing the words that help people can tell what she/he has to share or explain about thing, story, information, or idea that they have inside their mind which is difficult to explain or tell it with speaking. Beside that, writing needs some attention where there is own method also own principles that need grammar, judgment and also the concept. That is why writing needs some practical to make the writing skill improve, Safitri (2015).

Writing has more accuracy than speaking and the accuracy is requiring in it. For other hand the accuracy is much greater than speaking, example in written task, completing the application form also for another formal language, Riddel (2003). Follows by Nura (2003:71) she says that "Writing is not merely simbolically spoken language. Writing is a person way to express him/ herself and to addapt with the society.Through writing readers will understand the writer's way of thinking". Writing has four mains of the types, there are narrative, expository, descriptive, and persuasive.

For every level of the school such as elementary school level, junior high school level, senior high school level, and even in university where are the students are expected to master some types of writing. In this study, writer chooses the tenth grade senior high school student as the population to discuss about writing. And the type of the writing to discuss is narrative 
text. Narrative as one of the types of writing that used for students teaching and learning process moreover used in national exam.

Narrative is an interesting type of writing to learn, it tells a story that entertains the readers with the story inside. Ayres (2008) "Narrative text is a form of discourse that has been fixed by writing". And Kan says that "A narrative is meaningful sequence of events told in words. It is sequential in that events are ordered, not merely random. Sequence always involves (and usually other arrangements as well). A straightforward movement from first event to the last constitutes the simplest chronology". It means that a narrative text is a text which contains a story ordered the chronologically about something and the text can be enjoyed by the readers. Means that the writer should arrange the text interestingly.

In this study, the researcher found problem that many of tenth grade students do not know write correctly. They confuse to express their ideas that they have in their mind, they do not have passion or do not feel confidence to perform their English, moreover in writing. They are also less enthusiastic and less confident in writing English also low motivation to learn about it.

The writer is adding the local tourism as the topic to write in narrative text, where there is interesting story inside of the local tourism which should be known by the students. Most of the students do not know about the story of their local tourism and they also careless about their local tourism that actually near their dwelling which make them less knowledge about it. Means that many of them cannot tell/write correctly about the story of their local tourism that actually interesting to be known.

Local tourism is local place that popular with the beauty nature, story, or the historical heritage that make tourist or the local people feel interest and proud to visit that place. The local tourism that add by the writer is local tourism of North Sumatera that should be familiar for the students of SMA GKPI Medan, such as Maimun Palace and Parapat. Maimun palace was the palace that that built in 1888 by Sultan Maimun Al Rasyid, the architect of this palace was Captain Th. Van Erop, This palace is stand in Medan City where it brings many tourist to come and see the historical heritage. Parapat is located on the edge of Lake Toba, $176 \mathrm{kms}$ from Medan city, this place brings the tourist to see the beauty nature of Lake Toba, feel the fresh air and the water, and also see the historical heritage. Beside of those describtion about Maimun Palace and Parapat there are interesting story of them such as history of Maimun palace and Deli Sultan that called "Meriam Buntung" and also the history of Parapat that popular with the Lake Toba and the history of it called the legend of the Lake Toba. Writer hope this topic will raise the student interest of writing, love and knowledge about the local tourism and also improve the students ability in writing the narrative text.

The researcher saw that media learning is one of the solution to raise the students enthusiastic in learning english so it improve their ability in writing and raise up their love and knowledge to the local tourism. Media Learning as the learning and teaching device that available to be served in help students to get easier in understand the topic and help out to encourage students' sentiment, and idea in process of learning and teaching, Arief (2006).

The writer chooses guessing game as the media learning. Guessing game to denote fun and games in what thing to be guessed several of knowledge like words, phrase, story, place, of the thing, Muhamad Dini (2017). Guessing game is one of interesting and motivating thing that builds students spirit to be active to study and raise their focus to study so they can get what the topic talking about and the Guessing game lend the students no to feel bore for teaching and learning process. With adding the local tourism as the topic students are expect and hope the environmental love charge as an effort to raise their interest of environment and also hope that the students able to write narrative with their own idea about the local tourism history as well. 
The previous research that using guessing game as the method for teaching and learning about writing. It has been done by Safitri, Bambang Wijaya, and Syarif Husin, W Zahara and $S$ Fatimah with their title "The effectiveness of guessing game towards students' writing skills on descriptive text." They result of their research is guessing game significantly improve students' mastery on writing descriptive text. The effect of guessing game is strong in teaching writing descriptive text.

Based on the explaintion above, the researcher would like to find out "Does use Guessing Games media themed local tourism is affective for students achievement in writing narrative text at SMA GKPI PAMEN?"

\section{Research Methods}

The research of the effect using guessing game media themed local tourism on students' achievement in writing narrative text was experimental research. To collect the data, two classes of students get involved, there are the experimental class and the control class. Where the experimental class is the group that will be taught by using the guessing game media, meanwhile the control class is the group that will be taught by using the conventional method. The measurement of this technique study is pretest and posttest. The research was conducted at SMA GKPI PAMEN and the population for the research taken from grade tenth students that consist of 30 students.

The pre-test was done to find out some sample and the mean score of the students basic skill in writing the narrative text and to find out their basic knowledge about their local tourism history. The treatment was given in 3 meetings where there is the researcher give the treatment by playing the guessing game. Before start the game, the researcher will tell about the game's rules and give them some of the example to make sure them clearly understand about the game. Students will try to arrange their ideas from game and write about simple narrative text base on it after the guessing game is over. Following Have given the treatments, the post-test was given to the students whether use the guessing game media themed the local tourism is effective or not on students' achievement in writing narrative text. The items of the post-test were exactly the same as the one in the pre-test. It was intended to discover the mean score of the experimental group and the control group.

In analyzing the students result for the writing narrative text, the elements of writing was as the focused of the researcher such as the content, organization, vocabulary, and the grammar. The measurement technique of this study to produce the effect of using Guessing Game media themed local tourism on students' achievement in writing narrative text.

Table 1. Design of Research

\begin{tabular}{|l|l|l|l|}
\hline Group & Pre-Test & Treatment & Post-Test \\
\hline Experimental Class (X) X-I & $\checkmark$ & Using Guessing Game Media & $\checkmark$ \\
\hline Control Class (Y) X-II & $\checkmark$ & Using the Conventional Method & $\checkmark$ \\
\hline
\end{tabular}

In this research, the researcher used t-Test formula to calculate the difference cross the result of pre-test and post-test in experimental and control group. The result of this calculation was to found whether the using of guessing game has a significant effect to the students' writing narrative. The t-Test formula as the following:

$$
\mathrm{t}=\frac{M x-M y}{\sqrt{\frac{x D+y z}{N x+N y-z}}\left(\frac{1}{N x}+\frac{1}{N y}\right)}
$$


Which: $\quad \mathrm{M}_{\mathrm{x}}$ mean of the experimental group

$\mathrm{M}_{\mathrm{y}}$ : mean of the control group

$\mathrm{X}$ : the deviation square of the experimental group

$Y$ : the deviation square of the control group

$N_{x}$ the total number of samples of the experimental Group

$\mathrm{N}_{Y}$ : the total number of samples of the control group

The researcher will be ran the testing hypothesis. Testing the hypothesis will be done to find out whether the hypothesis is accepted or rejected. The basic of testing hypothesis in this research are:

- If t-observed > t-table, the alternative hypothesis (Ha) will be accepted and the null hypothesis (Ho) will be rejected.

- If t-observed < t-table, the null hypothesis (Ho) will be accepted and the alternative hypothesis (Ha) will be rejected.

\section{Result and Discussion}

The researcher was discovered the effect of using guessing game themed local tourism to find out wheter this media learning is effective or not for students achievement on writing narrative text to the tenth grade students of SMA GKPI PAMEN. The research was done and took the data from 2 classes those are $\mathrm{X} 1$ as the experimental class that taught using the guessing game and $\mathrm{X} 2$ as the control class that taught using the conventional method. Following in apllied this media learning to the tenth grade students of SMA GKPI PAMEN, the researcher found that the outcome was point out that significant dissimilarity between teaching the students using the guessing game and without using guessing game. Teaching the students about narrative text using guessing game was over effective than teaching the students about narrative text without the guessing game. From the mean score of the two groups was given it can be seen. The mean score of experimental class $(81,4)$ and the mean score of control class $(73,06))$. It showed that the experimental class score that apply guessing game media was higher than the control class whitout used the guessing game media. And testify that using guessing game media themed local tourism is effective on students' achievement in writing narrative text to the tenth grade students of SMA GKPI PAMEN. And the data score with the calculation which done to the students is below here:

Table 2. The Calculation of Experimental Group

\begin{tabular}{|l|l|l|l|l|l|}
\hline \multicolumn{7}{|c|}{ Experimental Class } \\
\hline No. & $\begin{array}{l}\text { Initial Name of } \\
\text { the Students }\end{array}$ & $\begin{array}{l}\text { Pre-test } \\
(\mathbf{X 1})\end{array}$ & $\begin{array}{l}\text { Post-test } \\
(\mathbf{X 2})\end{array}$ & $\begin{array}{l}\text { Deviation (d) } \\
\text { X2-X1=(X) }\end{array}$ & $\mathbf{d X}^{\mathbf{2}}$ \\
\hline 1. & BS & 36 & 76 & 40 & 1600 \\
\hline 2. & JM & 34 & 76 & 42 & 1764 \\
\hline 3. & JS & 48 & 84 & 36 & 1296 \\
\hline 4. & GV & 44 & 80 & 36 & 1296 \\
\hline 5. & KF & 38 & 74 & 36 & 1296 \\
\hline 6. & LD & 30 & 74 & 44 & 1936 \\
\hline 7. & LM & 60 & 82 & 22 & 484 \\
\hline 8. & MM & 62 & 86 & 24 & 576 \\
\hline 9. & MS & 44 & 74 & 30 & 900 \\
\hline 10. & MN & 34 & 78 & 44 & 1936 \\
\hline 11. & NW & 40 & 78 & 38 & 1444 \\
\hline
\end{tabular}




\begin{tabular}{|l|l|l|l|l|l|}
\hline 12. & NA & 38 & 78 & 40 & 1600 \\
\hline 13. & PN & 30 & 74 & 44 & 1936 \\
\hline 14. & PA & 36 & 74 & 38 & 1444 \\
\hline 15. & PW & 60 & 80 & 20 & 400 \\
\hline 16. & RH & 48 & 82 & 34 & 1156 \\
\hline 17. & RS & 48 & 80 & 32 & 1024 \\
\hline 18. & RS & 58 & 80 & 22 & 484 \\
\hline 19. & RP & 38 & 76 & 38 & 1444 \\
\hline 20. & RS & 58 & 80 & 22 & 484 \\
\hline 21. & RS & 64 & 88 & 24 & 576 \\
\hline 22. & SH & 38 & 78 & 40 & 1600 \\
\hline 23. & TA & 36 & 78 & 42 & 1764 \\
\hline 24. & RK & 40 & 76 & 36 & 1296 \\
\hline 25. & VY & 62 & 84 & 22 & 484 \\
\hline 26. & VM & 46 & 78 & 32 & 1024 \\
\hline 27. & VV & 40 & 78 & 38 & 1444 \\
\hline 28. & WS & 60 & 80 & 20 & 400 \\
\hline 29. & WN & 36 & 74 & 38 & 1444 \\
\hline 30. & YA & 58 & 88 & 30 & 900 \\
\hline Total & 1364 & 2442 & 1004 & 35.432 \\
\hline Mean & 45,46 & 81,4 & 33,46 & \\
\hline
\end{tabular}

From the outcome above, the deviation in experimental class was 1004 . The mean of deviation in experimental class was 33,46 . The quantity of deviation (Dx2) was 35.432.

Table 3. The Calculation of Control Group

\begin{tabular}{|l|l|l|l|l|l|}
\hline \multicolumn{5}{|c|}{ Control Class } \\
\hline No. & $\begin{array}{l}\text { Initial Name of } \\
\text { the Students }\end{array}$ & $\begin{array}{l}\text { Pre-test } \\
(Y 1)\end{array}$ & $\begin{array}{l}\text { Post-test } \\
(\text { Y2) }\end{array}$ & $\begin{array}{l}\text { Deviation (d) } \\
\text { Y2-Y1=(Y) }\end{array}$ & dY $^{2}$ \\
\hline 1. & AG & 50 & 78 & 28 & 784 \\
\hline 2. & AH & 40 & 75 & 35 & 1225 \\
\hline 3. & AS & 30 & 70 & 40 & 1600 \\
\hline 4. & AN & 40 & 70 & 30 & 900 \\
\hline 5. & AS & 40 & 70 & 30 & 900 \\
\hline 6. & AS & 40 & 70 & 30 & 900 \\
\hline 7. & BM & 62 & 76 & 14 & 196 \\
\hline 8. & BB & 50 & 76 & 26 & 625 \\
\hline 9. & CG & 50 & 76 & 26 & 625 \\
\hline 10. & CP & 50 & 76 & 26 & 625 \\
\hline 11. & DY & 50 & 70 & 20 & 400 \\
\hline 12. & DS & 40 & 70 & 30 & 900 \\
\hline 13. & DN & 40 & 70 & 30 & 900 \\
\hline 14. & EP & 60 & 80 & 20 & 400 \\
\hline 15. & ET & 50 & 72 & 22 & 484 \\
\hline 16. & EG & 68 & 78 & 10 & 100 \\
\hline 17. & ES & 30 & 70 & 30 & 900 \\
\hline 18. & FS & 40 & 74 & 34 & 1156 \\
\hline 19. & HT & 40 & 70 & 30 & 900 \\
\hline 20. & HH & 40 & 70 & 30 & 900 \\
\hline 21. & HS & 50 & 70 & 20 & 400 \\
\hline 22. & HM & 50 & 70 & 20 & 400 \\
\hline & & & & \\
\hline
\end{tabular}




\begin{tabular}{|l|l|l|l|l|l|}
\hline 23. & IB & 40 & 70 & 30 & 900 \\
\hline 24. & IH & 40 & 60 & 20 & 400 \\
\hline 25. & JM & 40 & 70 & 30 & 900 \\
\hline 26. & JA & 40 & 70 & 30 & 900 \\
\hline 27. & KH & 50 & 80 & 30 & 900 \\
\hline 28. & RS & 55 & 78 & 23 & 529 \\
\hline 29. & RN & 50 & 75 & 25 & 625 \\
\hline 30. & SH & 60 & 88 & 28 & 784 \\
\hline \multicolumn{2}{|l|}{ Total } & 1395 & 2.192 & 797 & 20.451 \\
\cline { 1 - 2 } Mean & 46,5 & 73,06 & 26,56 & \\
\hline
\end{tabular}

The quantity of Deviation (dY) in control class was 797 and the mean of deviation in control class was 26,56 . The quantity of deviation (dY)2 was 20.451

The $\mathrm{t}$-Test was calculating as the following:

$$
\mathrm{t}=\frac{M_{X}-M_{Y}}{\sqrt{\left[\frac{\Sigma x^{2}+\Sigma y^{2}}{N_{x}+N_{y}-2}\right]\left[\frac{1}{N_{x}}+\frac{1}{N_{y}}\right]}}
$$

$\mathrm{M}_{\mathrm{X}}=\sum \frac{x}{n}=\frac{1004}{30}=33,46$

$\mathrm{M}_{\mathrm{Y}} \quad=\sum \frac{y}{n}=\frac{747}{30}=24,9$

$\mathrm{dX}^{2}=\sum X^{2}-\frac{\left(\sum x^{2}\right)}{n}$

$=35.432-\frac{(1004)^{2}}{30}$

$=35.432-\frac{1.008 .016}{30}$

$=35.432-33.600$

$=1.832$

$\mathrm{dY}^{2}=\sum Y^{2}-\frac{\left(\sum y^{2}\right)}{n}$

$=20.451-\frac{(797)^{2}}{30}$

$=20.451-\frac{588.009}{30}$

$=20.451-18.600$

$=1.851$

$\mathrm{t}=\frac{M_{X}-M_{Y}}{\sqrt{\left[\frac{\Sigma x^{2}+\Sigma y^{2}}{N_{x}+N_{y}-2}\right]\left[\frac{1}{N_{x}}+\frac{1}{N_{y}}\right]}}$ 
$t=\frac{33,46-26_{z} 56}{\sqrt{\left[\frac{1883+1851}{80+80-2}\right]\left[\frac{1}{30}+\frac{1}{80}\right]}}$

$\mathrm{t}=\frac{6,9}{\sqrt{\left[\frac{3.689}{58}\right]\left[\frac{2}{80}\right]}}$

$\mathrm{t}=\frac{6,9}{\sqrt{[63,5][0,06]}}$

$\mathrm{t}=\frac{6,9}{\sqrt{[3,81]}}$

$\mathrm{t}=\frac{6 z 9}{1,95}$

$\mathrm{t}=3,53$

Build upon the calculation of $t$-test, it was found that $t$-observed $(3,53)$ was higher that $\mathrm{t}$-table $(1,672)$ for the value of $\mathrm{t}$-table for degree of freedom $(\mathrm{df})=\mathrm{Nx}+\mathrm{Ny}-2=30+30-2=58$ at the level significant $\alpha=0,05$. It can be seen as follows:

t-observed $>$ t- table $\quad(\alpha=0,05)$ with $\mathrm{df}=58$

$3,53>1,672 \quad(\alpha=0,05)$ with $\mathrm{df}=58$

So, it indicate that Ha was accepted and Ho was rejected. In other words, it indicate that using Guessing Game Media themed local tourism is intense effective into students' writing narrative text and raise their knowledge and love to the local tourism as well.

\section{Conclusion}

From the data that has found above, it shows that using guessing game media is effective for students' achievement in writing narrative text to the tenth grade students of SMA GKPI PAMEN. Guessing game media themed local tourism is good media learning in teaching writing narrative text. It is an effective media learning for students' achievement in teaching learning narrative text that raise the students interest of writing. Using game make the students put more attention to the topic was given. And the local tourism's themed make the students have more knowledge about the local tourism, raise their love and care to the environment.

This research showed that using guessing game media themed local tourism is effective from the data score have gotten. The experimental class which taught using guessing game, the posttest mean score was $(81,4)$ it is highger than control group which taught using the conventional method, the posttest mean score was $(73,06)$. The result of the t-test was 3,53 . conclude that guessing game media is an effective teaching method on students' achievement in writing narrative text to the tenth grade students of SMA GKPI PAMEN. 


\section{References}

Ayres, Lioness. (2013). Narrative text. Dec

Dwi M, Mega. (2009). The Use Of Guessing Game In Teaching Speaking. Bandung: Unpublished.

Englishindo. (2013). Narrative text. Dec 2013

Handoko, Muhamad Dini. (2017). The Concept Of Guessing Game

Meyers, Alan. (2005). Gateways to Academic Writing: Effective Sentences, Paragraphs, and Essays, New York: Pearson Education.

Oshima, A., and A Hogue. (2007). Introduction to Academic Writing. New York: Addison Wesley Longman.

repository.unmuha.ac.id. (2013). Chapter Two Theorytical Review

Safitri, Bambang Wijaya and Syarif Husin. (2015). The Effect of Guessing Game toward Students' Writing skill On Descriptive Text. 